\title{
УТИЛІЗАЦІЯ СТІЧНИХ ФЕНОЛВМІСНИХ ВОД ГАЗОГЕНЕРАТОРНИХ УСТАНОВОК ШЛЯХОМ МЕТАНОВОЇ АНАЕРОБНОЇ ПЕРЕРОБКИ
}

\author{
В.П. Клюс, канд. техн. наук, С.В. Клюс, канд. техн. наук, Г.О. Четверик, канд. техн. наук \\ Інститут відновлюваної енергетики НАН України, \\ 02094, вул. Гната Хоткевича, 20А, м. Київ, Україна.
}

Наведено результати експериментів з метанової анаеробної переробки конденсату сумісно з коров'ячим гноєм. Конденсат було отримано під час часткової газифікації березової тріски. Наведено вихід деревного вугілля та конденсату, сорбиійні показники деревного вугілля, а саме питому внутрішню поверхню та йодне число. Визначено концентрацію фенольних сполук в конденсаті. Проиес бродіння відбувався за мезофільної температури $35{ }^{\circ} \mathrm{C}$. Незважаючи на інгібування прочесу бродіння фенольними сполуками конденсату, щзо призвело до більш тривалої лаг-фази, має місие переробка органічних речовин конденсату в біогаз та інтенсифікація бродіння. Лаг-фаза під час бродіння конденсат-вмісних субстратів триває довще в 2,9-4,8 рази, ніж для контрольного субстрату, який не містив конденсату. Встановлено гранично допустиму

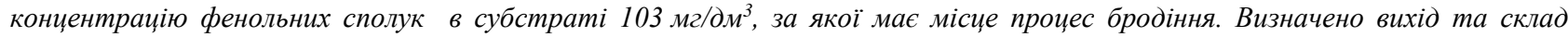
біогазу, ступінь переробки органічної речовини та фенольних сполук. Кумулятивний вихід біогазу з одинииі об'єму субстрату на 40,3-58,6 \% більший з конденсат-вмісних субстратів. Середня конщентрація метану у виробленому біогазі на 9,6-13,6 \% більша з конденсат-вмісних субстратів. Показано, щчо об'єм виробленого біогазу та вміст метану в біогазі підвишився за рахунок переробки фенольних сполук. При иьому деструкиія фенольних сполук в конденсат-вмісних субстратах становила від 45,5\% до 80,3\%. На основі отриманих експериментальних результатів розроблена принципова схема для промислової реалізації наведеного способу перероблення конденсату. Це дасть змогу використати фізичну теплоту генераторного газу або для підтримування сталої температури всередині біогазового реактора, або для попереднього підігрівання субстрату. Органічні кислоти, розчинна смола та фенольні сполуки, щчо присутні в конденсаті переробляються в біогазовому реакторі для отримання біогазу. Бібл. 13, табл.1, рис. 2.

Ключові слова: біогаз, конденсат, часткова газифікачія, метанове анаеробне бродіння.

\section{UTILIZATION OF PHENOL-CONTAINING WASTEWATER FROM GASIFIER PLANT BY METHANE ANAEROBIC DIGESTION}

\author{
V. Klius, cand. of technical science, S. Klius, cand. of technical science, H. Chetveryk, cand. of technical science \\ Institute of Renewable Energy of the National Academy of Sciences of Ukraine, \\ 02094, 20A Hnata Khotkevycha St., Kyiv, Ukraine.
}

The results of experiments on methane anaerobic digestion of condensate in combination with cow manure are presented. Condensate was obtained during partial gasification of birch chips. The yield of biochar and condensate, sorption parameters of biochar namely the specific internal surface and iodine value are given. The concentration of phenolic compounds in the condensate was determined. The digestion process took place at a mesophilic temperature of $35{ }^{\circ} \mathrm{C}$. Despite the inhibition of the digestion process by phenolic compounds of condensate which led to a longer lag phase there is a conversion of organic matter of condensate into biogas and intensification of digestion. Lag phase during digestion of condensate-containing substrates is up to 2,9-4,8 times longer than a control substrate that does not contain condensate. The maximum allowable concentration of phenolic compounds in the substrate is $103 \mathrm{mg} / \mathrm{dm}^{3}$ at which the digestion process takes place. The yield and composition of biogas, the degree of conversion of volatile solids and phenolic compounds are determined. The cumulative yield of biogas per unit volume of substrate is 40.3-58.6\% higher than that of condensate-containing substrates. The average concentration of methane in the produced biogas is 9.6-13.6\% higher than that of condensate-containing substrates. It has been shown that the volume of biogas produced and the methane content in biogas have increased due to the processing of phenolic compounds. The destruction of phenolic compounds in condensate-containing substrates ranged from $45.5 \%$ to $80.3 \%$. Based on the obtained experimental results a schematic diagram for the industrial implementation of the above method of condensate conversion is developed. This will allow the physical heat of the generator gas to be used either to maintain a constant temperature inside the biogas reactor or to preheat the substrate. Organic acids, soluble tar and phenolic compounds present in the condensate are processed in a biogas reactor to produce biogas. Ref. 13, tabl. 1, fig. 2.

Keywords: biogas, condensate, partial gasification, methane anaerobic digestion. 


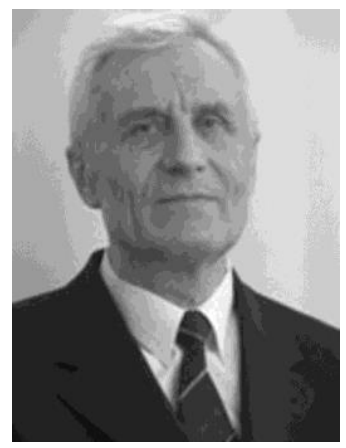

В.П. Клюс

V. Klius

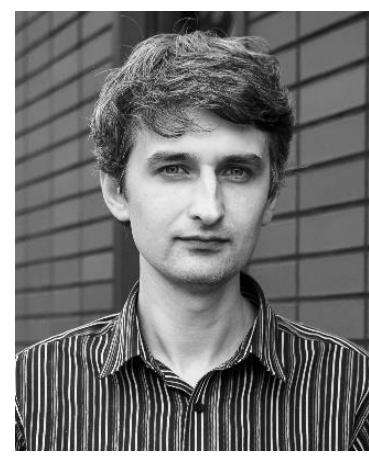

С.В. Клюс

S. Klius

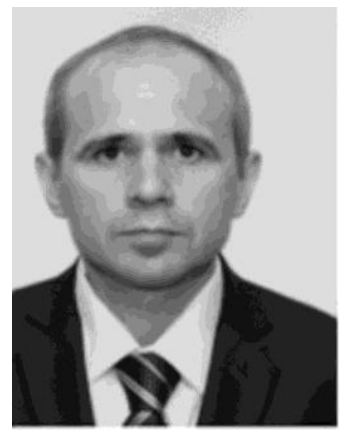

Г.О. Четверик

H. Chetveryk
Відомості про автора: працює в

Інституті відновлюваної енергетики НАН України, старший науковий співробітник. Кандидат технічних наук (1980 рік).

Освіта: Московський інститут хімічного машинобудування,

спеціальність «Машини і апарати

хімічних виробництв»

Наукова сфера: біоенергетика, газифікація біомаси, переробка органічних відходів.

Публікації: 102 наукових публікацій, у тому числі 30 патентів.

ORCID: 0000-0001-8536-3211

Контакти: тел./факс +38 (044) 206-28-09

e-mail: biomassa@ukr.net

Відомості про автора: працює в

Інституті відновлюваної енергетики НАН

України, старший науковий співробітник.

Кандидат технічних наук (2016 рік).

Освіта: Сумський Державний

Університет, магістр обладнання

хімічних виробництв та підприємств

будівельних матеріалів.

Наукова сфера: біоенергетика,

газифікація біомаси, переробка

органічних відходів.

Публікації: понад 30 наукових

публікацій, у тому числі 11 патентів.

ORCID: 0000-0002-5804-4925

Контакти: тел./факс: +38 (044) 206-28-09

e-mail: biomassa@ukr.net

Відомості про автора: працює в

Інституті відновлюваної енергетики НАН

України, старший науковий співробітник.

Кандидат технічних наук (2019 рік).

Освіта: Київський Національний

Університет імені Тараса Шевченко,

механіко-математичний факультет.

Наукова сфера: біогаз, переробка

органічних відходів.

Публікації: 46 наукових публікацій, у

тому числі 3 патенти.

ORCID: 0000-0001-9398-1968

Контакти: тел./факс: +38 (044) 206-28-09

e-mail: biomassa@ukr.net
Author information: Institute of Renewable Energy of NAS of Ukraine, senior researcher. PhD since 1980 year.

Education: Moscow Institute of Chemical Machine Building, specialty «Machine and Apparatus of Chemical Productions»

Research area: bioenergy, gasification of biomass, organic waste utilization.

Publications: 102 scientific publications, including 30 patents.

ORCID: 0000-0001-8536-3211

Contacts: tel./fax +38 (044) 206-28-09

e-mail: biomassa@ukr.net

Author information: Institute of Renewable Energy of NAS of Ukraine, senior researcher. PhD since 2016 year.

Education: Sumy State University, master of equipment of chemical productions and building materials enterprises.

Research area: bioenergy, gasification of biomass, organic waste utilization.

Publications: more than 30 scientific publications, including 11 patents.

ORCID: 0000-0002-5804-4925

Contacts: tel./fax: +38 (044) 206-28-09

e-mail: biomassa@ukr.net

Author information: Institute of Renewable Energy of NAS of Ukraine, senior researcher. PhD since 2019 year.

Education: Taras Shevchenko National University of Kyiv, Faculty of Mechanics and Mathematics.

Research area: biogas, organic waste utilization.

Publications: 46 scientific publications, including 3 patents.

ORCID: 0000-0001-9398-1968

Contacts: tel./fax: +38 (044) 206-28-09

e-mail: biomassa@ukr.net
Вступ. В Україні останнім часом використовують піролізні установки для виробництва деревного вугілля. Процес піролізу передбачає утворення шкідливих стоків, які необхідно знешкоджувати. Зазвичай, промислові стоки спочатку чистять фізико-хімічними, а потім біологічним способами, що вимагає значних капітальних вкладень, пов'язаних 3 будівництвом та функціонуванням очисних споруд.
Для охорони водойм від забруднень промислових стоків, які забруднені шкідливими i канцерогенними речовинами, стічні води потребують ефективної очистки. Ці води проходять кілька стадій очищення, останньою 3 яких традиційно $є$ біохімічна, заснована на видаленні фенолів, роданідів та інших забруднень. Так, для очищення стічних вод коксохімічного виробництва використовують фенол- i родан-руйнуючі мікроорганізми. Біологічне очищення протікає завдяки 
окисленню забруднень активним мулом, який складається 3 живих організмів, бактерій i твердого субстрату [1].

Завдяки роботі низки науковців [2-6] в Україні набула розвитку технологія окислювального піролізу застосована для отримання деревного вугілля 3 деревної $\mathrm{i}$ рослинної біомаси. Було отримано якісне, рівномірно обпалене деревне вугілля, вихід якого склав до $30 \%$ по сухій масі палива [2-4]. Під час переробки деревини підвищеної вологості (45$47,5 \%$ ) вдалося отримати активоване вугілля 3 площею питомої поверхні $402 \mathrm{~m}^{2} / \Gamma$ і йодним числом $32,2 \%$ [4]. Теплота згоряння горючого

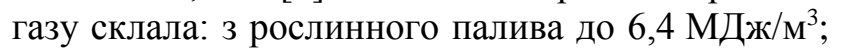
3 деревини до 7,6 МДж/м³ [2-4].

При охолодженні горючого газу, отриманого 3 деревини, особливо підвищеної вологості, утворюється конденсат, що містить фенольні сполуки, поліциклічні ароматичні вуглеводні, а також смолу. Джерелом конденсату $€$ гігроскопічна i пірогенетичної волога. Фенольний конденсат внаслідок свого шкідливого впливу не може скидатися у водойми. У цій статті наведені результати експериментальних досліджень утилізації фенольного конденсату біологічним методом.

Огляд біологічних методів переробки стічних фенольних вод. За сучасними даними кількість загального фенолу в конденсаті може досягати 6 г/дм ${ }^{3}$ [5]. Крім фенолу в конденсаті ідентифіковано понад 200 органічних сполук [6].

Допустимий вміст фенолу в стічних водах на вході в міську каналізацію становить $40 \mathrm{Mг} / \mathrm{m}^{3}$,

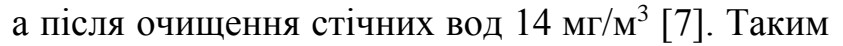
чином, стічні фенольні води повинні обов'язково очищатися, а біологічні методи очищення можна застосовувати тільки в тому випадку, якщо вміст фенолів в очищеній воді не перевищує гранично допустимих значень.

В період розвитку технології газифікації радянські біохіміки досліджували фенолдеструктивні бактерії, активність яких підтримувалася за максимальної концентрації фенолів 900 мг/дм³ . Була розроблена технологія очищення стічних вод в аеротенках 3 використанням згаданих бактерій. Однак вона не отримала широкого застосування через припинення газифікації твердого палива [8].

$\mathrm{y}$ наш час Ж. Джосс $\mathrm{i}$ А. Бенедек запропонували утилізувати конденсат газогенераторних станцій в анаеробному реакторі [9]. В роботі [10] наведені результати конверсії фенолу в біогаз в анаеробному реакторі за рівнянням $\quad \mathrm{C}_{6} \mathrm{H}_{5} \mathrm{OH}+4 \mathrm{H}_{2} \mathrm{O} \rightarrow 3,5 \mathrm{CH}_{4}+2,5 \mathrm{CO}_{2}$. Вихід біогазу для субстрату 3 фенолом збільшився в порівнянні зі субстратом, що не містив фенол. Фенол був повністю перероблений за 24 доби.

Задовільні результати показала переробка субстрату, що складається з міських стічних вод $\mathrm{i}$ синтетичної фенолвмісної води зі вмістом фенолу від 50 до $1000 \mathrm{мг} /$ дм $^{3}$ в біогазовому реакторі за температури $55^{\circ} \mathrm{C}$. Повна переробка фенолу, залежно від початкової концентрації, відбувалася протягом 5-32 діб [11].

3 наведених даних видно, що фенольні сполуки i жирні кислоти при певних концентраціях конвертуються в біогаз мікробними популяціями. Тому, мета роботи полягає у визначенні максимальної концентрації фенолу в субстраті для його утилізації в біогазовому реакторі.

Утилізація конденсату в біогазовому реакторі. Конденсат був отриманий під час часткової газифікації деревної тріски на установці, схема і опис роботи якої наведено в [4]. Температура газифікації склала $520-960{ }^{\circ} \mathrm{C}$. В результаті газифікації було отримано два цільових продукти - деревне вугілля і горючий газ. При частковій газифікації деревної тріски змішаних порід вологістю до $25 \%$ вихід деревного вугілля склав 25-30\% на суху масу палива. Сорбційні показники вугілля: питома внутрішня поверхня $69-178 \mathrm{~m}^{2} / \Gamma$; йодне число $16,5-18,7$.

При частковій газифікації тріски берези і верби вологістю до 47,5\% вихід деревного вугілля склав 9,8-15\% на суху масу палива. Сорбційні показники вугілля: питома внутрішня поверхня 220-402 м²/г; йодне число 30,0-42,0.

Для проведення експериментальних досліджень використовували конденсат, отриманий при охолодженні горючого газу 3 сухої березової тріски. Вихід конденсату склав 0,47 дм³/кг тріски. Властивості конденсату такі: масова концентрація фенольних сполук $1172 \mathrm{мг} /$ дм $^{3}$, хімічне поглинання кисню $73412 \mathrm{мг} /$ дм $^{3}, \mathrm{pH}=4,0$.

В Інституті відновлюваної енергетики НАН України проводили дослідження, в процесі яких здійснювали переробку конденсату сумісно 3 коров'ячим гноєм $[12,13]$. Переробку конденсату виконували на лабораторній біогазовій установці, схему якої наведено на рис. 1. 


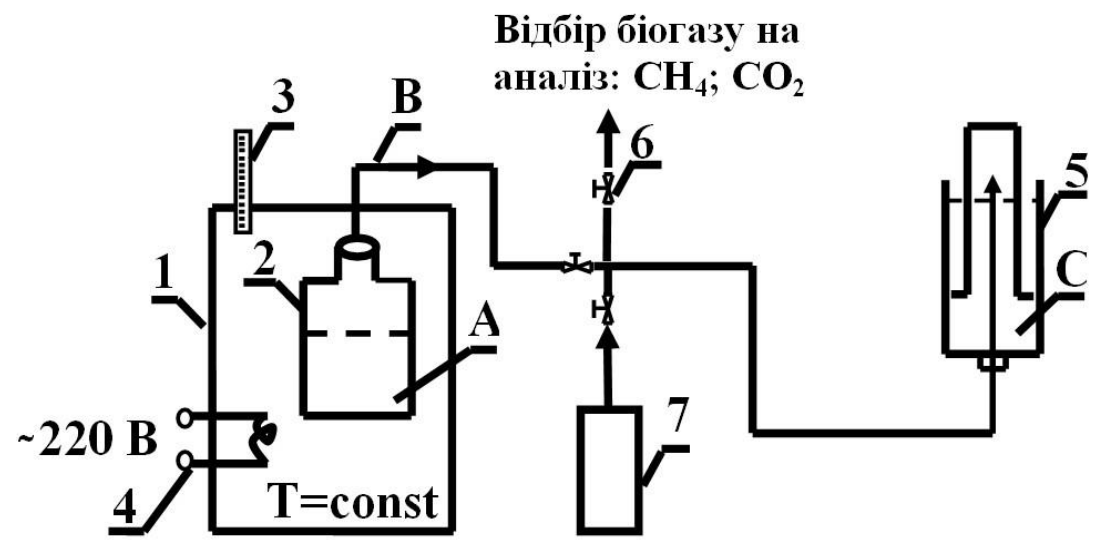

Рис. 1. Схема лабораторної біогазової установки: 1 - термостат, 2 - реактори, 3 - ртутний термометр, 4 - електричний нагрівач з регулятором температури, 5 - газгольдер, 6 - кран газовий, 7 - балон з азотом, $A$ - субстрат, $B$-біогаз, $\mathrm{C}$ - розчин $\mathrm{NaCl}$.

Fig. 1. Scheme of laboratory biogas plant: 1 -thermostat, 2 -reactors, 3 -mercury thermometer, 4 -electrical heater with temperature control, 5 - gasholder, 6 - gas faucet, 7 - balloon with nitrogen, $A$ - substrate, $B$ - biogas, $C$ - solution $\mathrm{NaCl}$.

\begin{abstract}
Лабораторна
складалася 3

біогазова установка наповненого водою теплоізольованого термостату, в якому й розміщувалися реактори, ртутний термометр i терморегулятор. Реактори герметично з'єднані 3 газгольдерами. Нерухома частина газгольдерів виставлена горизонтально i заповнена п’яти відсотковим розчином $\mathrm{NaCl}$ для запобігання розчинення вуглекислого газу у воді. На рухомій частині газгольдерів нанесено відмітки для візуального визначення об'єму виробленого біогазу. Для створення анаеробних умов всередині реактора газовий простір системи реактор-газгольдер безпосередньо перед початком експерименту продували азотом, об'єм якого втричі перевищував об'єм вказаного газового простору.

В процесі експериментів визначались такі показники: вологість та зольність вихідного субстрату, об'єм виробленого біогазу, об’ємну концентрацію метану та вуглекислого газу в біогазі, ступінь розкладу сухої органічної речовини та фенольних сполук. Загальний вміст фенольних сполук у субстраті визначали фотометричним методом в лабораторії «Київводоканалу» згідно з методикою виконання вимірювань. Було проведено дві серії експериментів за мезофільного режиму при температурі $35^{\circ} \mathrm{C}$. В обох експериментах було використано конденсат, отриманий під час газифікації сухої березової тріски. У другій серії експериментів конденсат містив значну кількість нерозчинної смоли.
\end{abstract}

Узагальнивши отримані експериментальні дані, виділимо таке: було встановлено, що на 60й день бродіння кумулятивний вихід біогазу

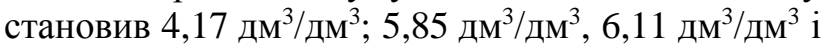
6,62 дм $^{3} /$ дм$^{3}$ при переробці субстратів, які містили фенольні сполуки 0 мг/дм³ $; 58,4$ мг/дм³ $70,8 \mathrm{мг} /$ дм $^{3}$ i $103 \mathrm{мг} /$ дм $^{3}$ відповідно. Кумулятивний вихід біогазу визначався в перерахунку на одиницю субстрату. Для субстрату, який містив фенольні сполуки 140 мг/дм ${ }^{3}$, лаг-фаза тривала більш як 50 днів, тобто вміст фенолу був вищим за граничне значення. Для обох експериментів було встановлено однаковий допустимий вміст конденсату в субстраті 103 мг/дм³ процес бродіння мав місце $[12,13]$.

Середня концентрація метану у виробленому біогазі, отриманого при переробці субстратів, які містили фенольні сполуки 0 мг/дм $м^{3} ; 58,4$ мг/дм ${ }^{3} ; 70,8$ мг/дм ${ }^{3}$ і 103 мг/дм ${ }^{3}$ був такий: $56,6 \% ; \quad 66,2 \% ; \quad 66,9 \%$ та $70,2 \%$ відповідно. Очевидно, що об'єм виробленого біогазу та вміст метану в біогазі підвищився за рахунок переробки фенольних сполук.

В табл. 1 наведено дані концентрації фенольних сполук в конденсат-вмісних субстратах до початку переробки в біогазовому реакторі й на 27-у добу бродіння. При цьому тривалість бродіння відповідає середньому часу перебування субстрату в промислових біогазових установках. 
Таблиця 1. Ступінь деструкції фенольних сполук конденсату.

Table 1. Degree of destruction of phenol in the condensate.

\begin{tabular}{|c|c|c|c|}
\hline \multirow{2}{*}{$\begin{array}{c}\text { Вміст } \\
\text { конденсату в } \\
\text { субстраті, \% }\end{array}$} & \multicolumn{2}{|c|}{$\begin{array}{c}\text { Загальний вміст фенольних сполук, } \\
\text { мг/дм }\end{array}$} & $\begin{array}{c}\text { Ступінь деструкції } \\
\text { фенольних сполук, } \\
\%\end{array}$ \\
\cline { 2 - 3 } & $\tau=0$ & $\tau=27$ доби & 80,3 \\
6 & 58,4 & 22,6 & 71,2 \\
8 & 70,8 & 30,2 & 45,5 \\
\hline
\end{tabular}

Як бачимо, ступінь деструкції фенольних сполук конденсату становить від 45,5\% до $80,3 \%$ на 27-у добу бродіння. Зі збільшенням масової частки конденсату в субстраті ступінь деструкції фенольних сполук конденсатів зменшується.

Підсумувавши отримані результати проведених експериментів, було встановлено, що:

- тривалість лаг-фази для процесу бродіння конденсат-вмісних субстратів в 2,9-4,8 рази довша, ніж для контрольного субстрату, який не містив конденсату;

- iз конденсат-вмісних субстратів утворилося більше біогазу в порівнянні 3 контрольним. Вихід біогазу з одиниці об'єму субстрату на 40,3-58,6\% більший 3 конденсатвмісних субстратів. Сумарна концентрація метану в біогазі на 9,6-13,6\% більша 3 конденсат-вмісних субстратів в порівнянні 3 контрольним;

- концентрація фенольних сполук в субстраті не має перевищувати $103 \mathrm{мг} /$ дм³ $^{3}$. Ступінь деструкції фенольних сполук конденсату становить від 45,5\% до $80,3 \%$ на $27-y$ добу бродіння.

Для промислової реалізації способу перероблення конденсату розроблена принципова схема, яка наведена на рис. 2.

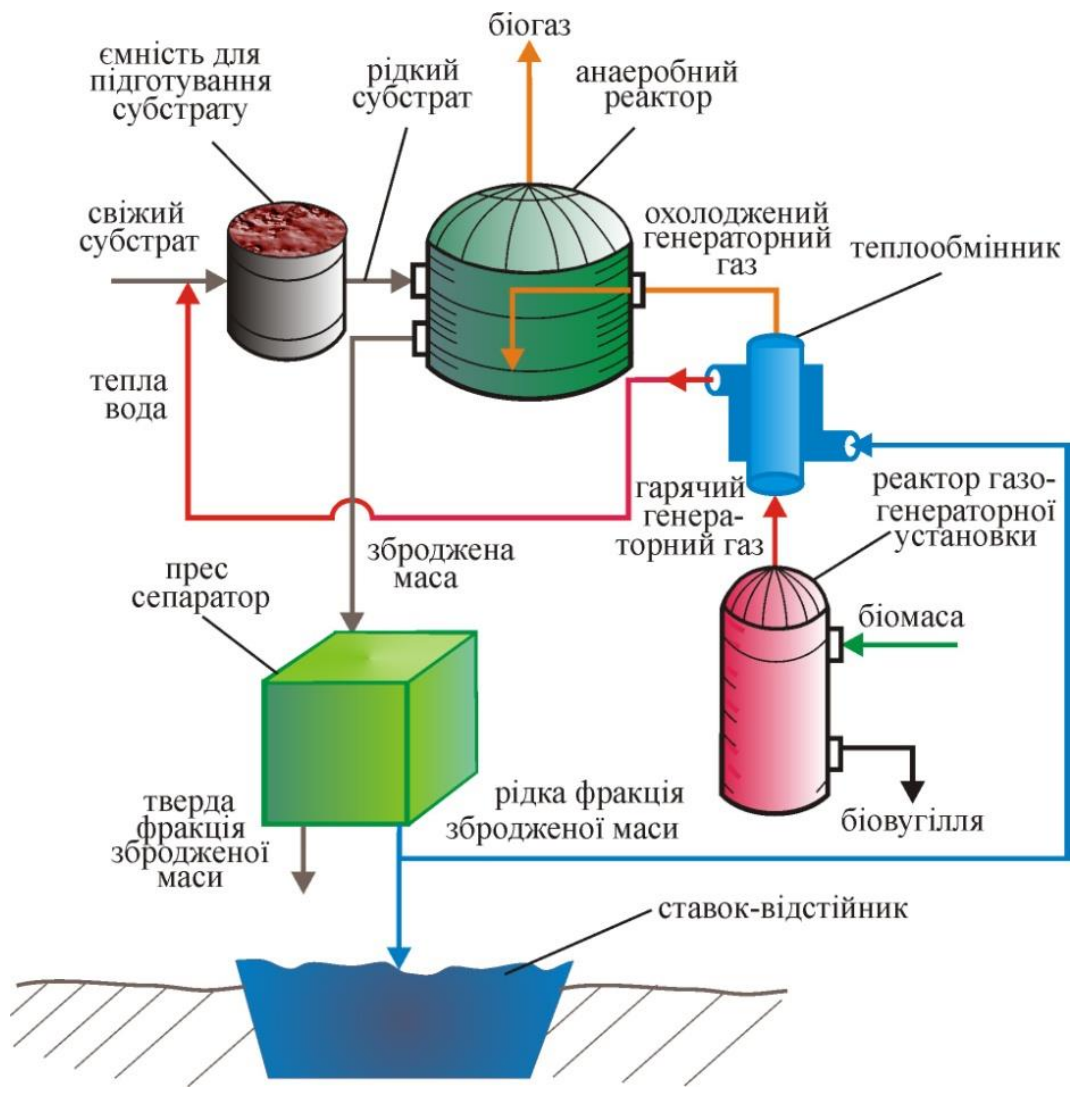

Рис. 2. Комплексна енергетична установка.

Fig. 2. Complex power plant. 
На основі отриманих результатів створено комплексну енергетичну установку, яка складається 3 газогенератора та анаеробного реактора. Вироблений в газогенераторі газ спрямовується в анаеробний реактор, де він охолоджується, конденсується волога газу та органічні речовини, які змішуються з коров'ячим гноєм. Генераторний газ барботує через субстрат, перемішує його, руйнує кірку на поверхні субстрату, змішується з біогазом і спрямовується в дизель-генератор для виробництва електричної енергії.

Переваги сумісної роботи біогазової та газогенераторної установок такі:

- фізична теплота генераторного газу використовується або для підтримування сталої температури всередині біогазового реактора, або для попереднього підігрівання субстрату;

- органічні кислоти, розчинна смола, фенольні сполуки слугують сировиною для отримання біогазу;

- при барботуванні генераторного газу через шар субстрату відбувається його перемішування та руйнування кірки на поверхні субстрату.

Висновок: Встановлено можливість
утилізації стічних фенольних вод газогенераторних установок в біогазовій установці без застосування спеціальних бактерій. Це дозволить перероблювати стічні фенольні води в існуючих промислових біогазових комплексах, кількість яких постійно зростає.

1. Иванченко А.В., Дупенко О.О., Жарова О.В. Усовершенствование технологии биологической очистки сточных вод коксохимического предприятия с использованием химических добавок. Збірник наукових праць Дніпродзержинського державного технічного університету. Технічні науки 2. 2015. С. 178-182.

2. Кремнева К.В. Підвищення ефективності двостадійного процессу газифікації дрібнодисперсної біомаси для когенераційних установок малої потужності: автореф. дис. на здобуття наук. ступеня канд. техн. наук: спец. 05.14.06. Дніпро. 2015. 21 с

3. Карп И.Н., Мариевой Е.П., Пьяных К.Е., Антошук Т.A., Пьяных К.К. Исследование и внедрение процессов газификации углей и биомассы с целью замещения природного газа. Энерготехнологии и ресурсосбережение. 2014. № 4. С. 3-11.

4. Клюс С.В. Енергоефективне перетворення біомаси в горючий газ і біовугілля в газогенераторах щільного шару палива: автореф. дис. на здобуття наук. ступеня канд. техн. наук: спец. 05.14.08. К. 2016. 24 с.

5. Пьяных K.K. Децентрализованное производство электроэнергии с использованием газификации биомассы. Результаты исследований. тези доповідей. Міжнародна науково-практична конференція «Відновлювана енергетика та енергоефективність у XXI столітті». К. 26-28 вересня 2018 p. C. $571-575$.

6. Rajvanski A.K. Biomass gasification. Alternative energy in agriculture. CRC Press. 1986. Vol. II. Pp. 83-102.
7. Алєєксенков А.М. Правила приймання та скиду стічних вод підприємств у систему каналізації. Дніпро. КП Дніпроводоканал. 2012. 38 с.

8. Канторов М.B. Газогенераторы и газогенераторные станции в металлургической промышленности. М. Металлургиздат. 1958. $467 \mathrm{c}$.

9. Josse J.C., Benedek A. Syngas Biomethanation Process and Anaerobic System. Pat. Pub. No. US 2015/0027179 A1

10. Fang H., Liu $Y$., Ke S., Zhang T. Anaerobic Degradation of Phenol In Wastewater at Ambient Temperature. Water Science and Technology. IWA Publishing. 2004. Vol. 49. No. 1. 95-102.

11. Fang H., Liang D., Zhang T., Liu $Y$. Anaerobic Treatment of Phenol In Wastewater Under Thermophilic Condition. Water Research. 2006. Vol. 40. 427-434.

12. Клюс В.П., Четверик Г.О. Переробка конденсату газогенераторної установки в біогаз. Відновлювана енергетика. 2017. № 4. С. 84-92.

13. Клюс В.П., Четверик Г.О. Сумісне анаеробне бродіння гнойових відходів та конденсату газогенераторної установки. Відновлювана енергетика. 2017. № 3. С. 80-86.

\section{REFERENCES}

1. Yvanchenko A.V., Dupenko O.O., Zharova O.V. Usovershenstvovanye tekhnolohyy byolohycheskoy ochystky stochnykh vod koksokhymycheskoho predpryyatyya s yspolzovanyem khymycheskykh dobavok. [Improving the technology of biological wastewater treatment of a coke chemical plant using chemical additives]. Zbirnyk naukovykh prats Dniprodzerzhynskoho derzhavnoho tekhnichnoho universytetu. Tekhnichni nauky 2. 2015. Pp. 178-182. [in Russian].

2. Kremnyeva K.V. Pidvyshchennya efektyvnosti dvostadiynoho protsessu hazyfikatsiyi dribnodyspersnoyi biomasy dlya koheneratsiynykh ustanovok maloyi potuzhnosti. [The two-stage efficiency of the gasification process of the dispersed biomassi for cogeneration plants of small need]. avtoref. dys. na zdobuttya nauk. stupenya kand. tekhn. nauk. spets. 05.14.06. Dnipro. 2015. 21 p. [in Ukrainian].

3. Karp I.N., Martsevoy Ye.P., Pyanykh K.Ye., Antoshchuk T.A., Pyanykh K.K. Issledovaniye i vnedreniye protsessov gazifikatsii ugley i biomassy s tsel'yu zameshcheniya prirodnogo gaza. [Research and implementation of coal and biomass gasification processes to replace natural gas]. Energotekhnologii i resursosberezheniye. [Energy Technologies and Resource Saving]. 2014. No. 4. Pp. 3-11. [in Russian].

4. Klyus S.V. Enerhoefektyvne peretvorennya biomasy v horyuchyy haz i biovuhillya $\mathrm{v}$ hazoheneratorakh shchilnoho sharu palyva. [Energy efficient conversion of biomass into combustible gas and biochar in gas generators of dense fuel layer]. avtoref. dys. na zdobuttya nauk. stupenya kand. tekhn. nauk: spets. 05.14.08. K. 2016. 24 p. [in Ukrainian].

5. Pyanykh K.K. Detsentralizovannoye proizvodstvo elektroenergii s ispol'zovaniyem gazifikatsii biomassy. Rezul'taty issledovaniy. [Decentralized electricity production using biomass gasification. Research results]. tezy dopovidey. Mizhnarodna naukovo-praktychna konferentsiya «Vidnovlyuvana enerhetyka ta enerhoefektyvnist u XXI stolitti». [International scientific-practical conference "Renewable energy and energy efficiency in the XXI century]. K. 26-28 September 2018 year. Pp. 571-575. [in Russian].

6. Rajvanski A.K. Biomass gasification. Alternative energy in agriculture. CRC Press. 1986. Vol. II. Pp. 83-102. [in English].

7. Alyeyeksenkov A.M. Pravyla pryymannya ta skydu stichnykh vod pidpryyemstv u systemu kanalizatsiyi. [Rules for 
receiving and discharging wastewater from enterprises into the sewerage system]. Dnipro. KP Dniprovodokanal. 2012. 38 p. [in Ukrainian].

8. Kantorov M.V. Gazogeneratory i gazogeneratornyye stantsii $\mathrm{v}$ metallurgicheskoy promyshlennosti. [Gas generators and gas generating stations in the metallurgical industry]. $M$. Metallurgizdat. 1958. 467 p. [in Russian].

9. Josse J.C., Benedek A. Syngas biomethanation process and anaerobic system. Pat. Pub. No. US 2015/0027179 A1. [in English].

10. Fang H., Liu Y., Ke S., Zhang T. Anaerobic degradation of phenol in wastewater at ambient temperature. Water Science and Technology: IWA Publishing, 2004. Vol. 49. No. 1. Pp. 95-102. [in English].

11. Fang H., Liang D., Zhang T., Lia Y. Anaerobic treatment of phenol in wastewater under thermophilic condition. Water research. 2006. Vol. 40. Pp. 427-434. [in English].

12. Klius V.P., Chetveryk H.O. Pererobka kondensatu hazoheneratornoyi ustanovky $\mathrm{v}$ biohaz. [Conversion of condensate of the syngas plant into biogas]. Vidnovluvana energetika. 2017. No. 4. Pp. 84-92. [in Ukrainian].

13. Klius V.P., Chetveryk H.O. Sumisne anaerobne brodinnya gnoyovih vidhodiv ta kondensatu gazogeneratornoyi ustanovki. [Simultaneous anaerobic digestion of manure waste and condensate of a syngas plant]. Vidnovluvana energetika. 2017. No. 3. Pp. 80-86. [in Ukrainian].

\section{УТИЛИЗАЦИЯ СТОЧНЫХ ФЕНОЛЬНЫХ ВОД ГАЗОГЕНЕРАТРНЫХ УСТАНОВОК}

В.П. Клюс, канд. техн. наук, С.В. Клюс, канд. техн. наук, Г.А. Четверик, канд. техн. наук

Институт возобновляемой энергетики НАН Украины, 02094, г. Киев, ул. Гната Хоткевича 20А

Приведень результаты экспериментов метановой анаэробной переработки конденсата совместно с коровьим навозом. Конденсат был получен при частичной газификации березовой щеепы. Приведены выход древесного угля и конденсата, сорбиионные показатели древесного угля, а именно удельную внутреннюю поверхность и иодное число. Определено концентрацию фенольных соединений в конденсате. Проиесс брожения происходил при мезофильной температуре $35{ }^{\circ} \mathrm{C}$. Несмотря на ингибирование проиесса брожения фенольными соединениями конденсата, что привело к более длительной лаг-фазы, имеет место переработка органических веществ конденсата в биогаз и интенсификачия брожения. Лаг-фаза во время брожения конденсат-содержащчих субстратов длится дольше в 2,9-4,8 раза, чем для контрольного субстрата, который не содержал конденсата. Установлена предельно допустимая кониентрация фенольных соединений в субстрате 103 мг/дм ${ }^{3}$, при которой имеет место проиесс брожения. Определены выход $u$ состав биогаза, степень переработки органического вещеества и фенольных соединений. Кумулятивный выход биогаза с единицы объема субстрата на 40,3-58,6\% больие с конденсат-содержаших субстратов. Средняя кониентраиия метана в биогазе на 9,6-13,6\% больше с конденсат-содержащих субстратов. Показано, что объем производимого биогаза и содержание метана в биогазе повысился за счет переработки фенольных соединений. При этом деструкция фенольных соединений в конденсатсодержащчих субстратах составляла от 45,5\% до 80,3\%. На основе полученных экспериментальных результатов разработана приниипиальная схема для промышленной реализации приведенного способа переработки конденсата. Это позволит использовать физическую теплоту генераторного газа или для поддержания постоянной температуры внутри биогазового реактора, или для предварительного подогрева субстрата. Органические кислоты, растворимая смола и фенольные соединения, присутствуюшие в конденсате перерабатываются 6 биогазовых реакторах для получения биогаза. Библ. 13, табл. 1, рис. 2.

Ключевые слова: биогаз, конденсат, частичная газификация, метановое анаэробное брожение.

Стаття надійшла до редакції 06.05.20 Остаточна версія 12.06.20 